<smiles>CC(C)c1cc(Oc2c(Br)cc(NC(=O)CC(=O)O)cc2Br)ccc1O</smiles><smiles>CCc1cc(Cc2c(C)cc(OC(O)O)cc2C)ccc1O</smiles>

\title{
THERAPY
}

\section{Thyroid hormone receptor agonists to reduce cholesterol levels?}

Homozygous familial

hypercholesterolaemia is a rare genetic disorder in which patients lack functional LDL receptors (LDLRs). However, a new study in $\mathrm{LDLR}^{-/-}$mice suggests that thyroid hormone receptor (TR) agonists have potential as treatments for this disorder.

Current treatment options for patients with homozygous familial hypercholesterolaemia have limited longterm effectiveness. Many conventional therapies for high serum cholesterol levels target LDLRs and so are ineffective for treating patients with this disorder.

In a previous study, administering the TR agonist GC-1 to wild-type mice reduced serum cholesterol levels, even though LDLR expression levels did not increase. A team led by Kevin Phillips of the Methodist Hospital Research Institute, Houston, USA has now found that GC- 1 reduces serum cholesterol levels in $\mathrm{LDLR}^{-/-}$mice, suggesting that this TR agonist acts via an LDLR-independent mechanism.

"We assumed that LDLRs mediated the reduction in cholesterol levels induced by thyroid hormones," says Phillips. "We were very surprised to find that not only did triglyceride levels decline sharply in mice lacking LDLRs following administration of GC-1, but that cholesterol levels also decreased strikingly."

The researchers found that, following GC-1 administration, expression of cholesterol 7-a-monooxygenase, a protein involved in hepatic synthesis of bile acids from cholesterol, was increased sevenfold and the amount of bile acids excreted in faeces increased 2.5 -fold. Additionally, the investigators showed that administration of either another TR agonist, KB2115, or of $\mathrm{T}_{3}$ reduced serum cholesterol levels in $\mathrm{LDLR}^{-/-}$mice, indicating that this mechanism of action is not unique to GC-1. "We think that TR activation induces expression of cholesterol 7-a-monooxygenase, which helps to dispose of excess cholesterol," explains Phillips. "This enzyme has the same role in humans."

TR agonists, therefore, have potential as cholesterol-reducing therapies for patients lacking LDLRs. "Our data suggest that TR agonists work via a different mechanism than do most other cholesterol-lowering drugs, including statins, and that they might be useful in treating patients for whom current therapies are either ineffective or poorly tolerated," says Phillips.

Fiona Mitchell

Original article Lin, J. Z. et al. Thyroid hormone receptor agonists reduce serum cholesterol independent of the LDL receptor. Endocrinology doi:10.1210/en.2011-2081 